\title{
APPROACHES TO RELIGIOUS POETRY IN POLISH AND ANGLOPHONE SCHOLARSHIP. A COMPARATIVE OVERVIEW
}

\section{KEY WORDS}

religious literature; religious poetry; literary criticism; the sacred in literature

The present article surveys various theoretical frameworks for the analysis of religious poetry, formulated in Polish, as well as Anglophone, ${ }^{1}$ scholarship. Its aim is threefold. First, it proposes an introductory overview of the body of theoretical studies of religious poetry in English. Secondly, it offers an analogous survey of Polish criticism on this matter, which so far remains hardly available to international readership. Thirdly, it compares the two critical traditions, pointing to some tendencies that are universal to the scholarship on religious poetry at large, and to those that are characteristic only of Polish or Anglophone critical thought.

The criterion used when selecting studies for the overview was their explicit recognition of "religious poetry" or "poetry and religion" as the subject of interest. ${ }^{2}$ The two general groups into which the theoretical studies of religious poetry analyzed below could be divided are on the one hand, studies that attempt at formulating a specific definition of the term "religious poetry", thus prescriptively

Joanna Matyjaszczyk - dr, Department of English Studies in Drama, Theatre and Film, Institute of English Studies, Faculty of Philology, University of Łódź, ul. Pomorska 171/173, 90-236 Łódź; e-mail: joanna.matyjaszczyk@uni.lodz.pl; https://orcid.org/0000-0001-7282-3434.

1 By "Anglophone" I mean written in English - mainly British, American and Australian.

2 Studies focused on narrower or broader categories such as, for example, "Christian poetry" or "metaphysical poetry" were not included in the corpus. It should be noted, however, that the terminology used did not necessarily agree with the de facto scope of the enquiries, and in practice "religious poetry", as used in some of the studies, had a clearly Christian tinge (see point three in the concluding section below). 
narrowing down its scope, and, on the other hand, those that propose a typology of religious poetry or discuss the relationships between poetry and religion in general, assuming a broader, more descriptive perspective. While each of these groups has its representatives among both Polish and Anglophone studies, the narrow approach (section one below) is more popular in Anglophone criticism, while in the case of the broad approach (sections two and three below) this proportion is reversed.

\section{Narrow Approaches: Defining "Religious Poetry"}

Scholars that formulate narrow, focused definitions of religious poetry tend to assume, either explicitly or implicitly, a certain function that such poetry fulfils and a specific understanding of the religious act/experience that then governs their approach. Among the expressively oriented understandings - that is, ones assuming that religious poetry is to express religious experience of either an author or a speaker in a poem - is one proposed by Reuven Tsur. As Tsur sees it, "one of the purposes of religious poetry is, typically, to reproduce effects characteristic of religious experience, or at least to display them" (Tsur 2003: 19); in other words, it is a "verbal imitation of some religious experience" (Tsur 2003: 19). For Tsur, the "precision of the translation" does not depend on the strength of experience, but "on how fine-grained the sign units of the system are" (Tsur 2003: 29). He illustrates his point using onomatopoeia as an analogy, that is, people's attempts to translate an infinite set of different noises with the use of a small number of speech sounds (Tsur 2003: 29). As Tsur explains, our acceptance of this translation results not from the fact that the sounds produced in nature and in speech are identical or particularly similar, but because there is something equivalent in their qualities (Tsur 2003: 29). Now, the task of poetry, as "a complex of semiotic systems", is to choose the most adequate "verbal strategies for capturing the felt qualities of such religious experiences as ecstasy, meditation or mystic experience", bearing in mind that there is no "one to one relationship" between these strategies and the qualities of the experience translated (Tsur 2003: 30). Even though the success of the whole enterprise depends here on the poetic devices that a given language offers, the very notion of the translation of "the felt qualities" places the personal religious experience at the centre of the project - there can be no translation without material to be translated, no matter how fine-grained the tools at hand are. The understanding of religious poetry proposed by Tsur is therefore a product of combining the expressive function of poetry and a narrow understanding of religious experience as an individual, non-discursive experience of meditation, ecstasy, or mystical involvement. 
Were it not for the fact that a substantial part of Helen Gardner's Religious Poetry: a Definition is devoted to a polemic with expressive-oriented definitions by various anthologists of religious poetry, one could suppose that hers belongs to the very same category. The popular fragment of Gardner's argument which is most often quoted as her definition is the one where she states that religious poetry is poetry that "treats of revelation and of man's response to revelation" (Gardner 1983: 135), but this concise phrase does not convey the key idea behind Gardner's understanding of religious poetry, which is the sense of commitment. Gardner states that what distinguishes meditative or philosophical poetry from religious poetry is that the poems belonging to the two former categories "are not written out of that sense of commitment or obligation which is the essence of religion" (Gardner 1983: 134). As she further explains,

the peculiar interest and the peculiar beauty of religious poetry lies in the fact that the poet who writes as a religious man does write in fetters. He writes as a man committed and his commitment, even if it is not stated, is implied. Whether he attempts to render in his own words and images the substance of the revelation received, or to render his response to it, he asks the reader to accept, at least during the reading of the poem, truths which are not presented as personal discoveries, values that are not his individual values, and to measure the experiences treated against standards that the poem itself does not create but whose existence it takes for granted (Gardner 1983: 135).

The difference between her approach and those she criticizes is that a poet here does not express him- or herself, that is, something within them, but rather something given to them, their poetry being a reaction to that gift from the outside, as opposed to a response to their own, individual feeling and experience. And thus we face a paradox - the core of Gardner's understanding of religious poetry consists in treating it as a voice responding to revelation somehow independently of the poet, but in order to distinguish this understanding of religious poetry from those which focus on individual religious experience, she refers to the commitment and obedience of an author to "what are felt to be imperatives from without the self that are binding" (Gardner 1983: 134; emphasis added). This apparent contradiction can be resolved, however, once it is assumed that Gardner is not in fact opposed to the expressive function of poetry, but to the combination of this function with the understanding of a religious act as a personal emotional experience that leads to an idiosyncratic concept or impression of the transcendent/deity. She opts for seeing religion as revelation, doctrine and a set of imperatives for those who are willing to accept them as binding in an act of religious commitment. Gardner focuses her attention above all on what 
she sees as the proper understanding of religion and religious acts and infers her definition of religious poetry from that.

Apart from expressing religious feeling or commitment, some other functions hinted at in scholarship on religious poetry are evoking feeling or experience, teaching or explaining and building a relationship (with the deity or a community of believers, depending on the concept of religious act assumed by a given critic). The focus on the impressive function of religious poetry (arousing religious feeling) is visible in one of the earliest modern essays on the topic in Polish criticism. The masterpieces of religious poetry are, according to the author of this essay, Ignacy Chrzanowski, only those poems which "evoke in a reader's or listener's soul simultaneously aesthetic and religious feelings" (Chrzanowski 1935: 69). Chrzanowski states openly that his definition entails a highly subjective approach. He admits that such criteria make the selection of poems falling under them a matter of individual choice (Chrzanowski 1935: 69). The role of religious poetry as an element of religious teaching is brought to the fore in Polish kerygmatic approach, ${ }^{3}$ initiated by Marian Maciejewski, which, while not tantamount to religious instruction or evangelization, sees poetry (and literature as well as other arts) mainly in the light of the catechetical function (Piekarski 2014: 40). One last function only briefly signalled by some critics is that of maintaining a relationship - the phatic function. Gardner notes that in hymns, discussed as a special case of religious poetry, the presentation of doctrine and mythology is expected not to be "too original in its images and phrasing" and to focus on the stock symbols already known by the congregation since their ultimate purpose is not so much to provide fresh insights, but to "create a sense of belonging to a continuing fellowship", as she quotes after George Sampson (Gardner 1983: 156-157). These remarks are of a marginal character and do not come to the fore as crucial for her understanding of religious poetry, but they nonetheless point to a function of religious poetry otherwise remaining largely unrecognized: that of holding people together and preserving that which constitutes the bond. Pezzini also hints at the phatic function, though here it is

3 Piekarski explains the terminological problem in Polish, where "krytyka" ("critique"/ "criticism") has a different meaning than in English or French and does not refer to literary-theoretical studies but to presenting and evaluating a literary work based on the criteria assumed by a given critic. The latter is, according to Piekarski, the right context in which to put the "kerygmatic approach" (Piekarski 2014: 32). I have translated the term "krytyka kerygmatyczna" as "kerygmatic approach" just to distinguish it from "criticism" used throughout my article as synonymous to "literary-theoretical study". The kerygmatic approach is excluded from the scope of literary studies also by Piotr Nowaczyński (1996: 20), Zofia Zarębianka (2008: 28) and Maria Jasińska-Wojtkowska (2003: 57). 
about maintaining the relationship with the transcendental being, and not with other members of the community. He proposes

the perception of the gap between the natural world and the supernatural, and the consequent implication of a being beyond the visible, as the main features characterizing religious poetry. The response to this transcendental being can take different forms [...]. This invisible being can be prayed to or insulted, lovingly accepted or aggressively questioned, celebrated or rejected, but since one feels his presence or the need of him, he is there, and can be addressed. The language and poetry produced by such attitudes is religious (Pezzini 2003: 50).

Pezzini presents the feeling of a transcendental being or the need of it as a prerequisite for composing religious poetry and as its defining feature. The function of religious poetry understood in this way is a combination of expressing this feeling and addressing the transcendental being, thus entering into some kind of relationship with it.

A possible outcome of assuming narrow prescriptive criteria is - apart from formulating a single definition of religious poetry - rejecting the very possibility of religious poetry. This scenario is a consequence of the presuppositions concerning poetry and religious experience turning out to be incompatible, so that combining the two results not in a delimitation of a common denominator, but in an empty set. This stance, an inheritance of, on the one hand, Samuel Johnson's eighteenth-century argument against religious poetry and, on the other hand, T.S. Eliot's concept of religious poetry as "minor poetry" is represented by Morris Dickstein, who assumes that the religious attitude ("achieved faith") involves "the confidence of being saved, of having found a single, all-embracing truth" (Dickstein 2000: 137) and the consequent acceptance of being bound by dogma, divine guidance and authority (Dickstein 2000: 150), at the same time understanding poetry as a free personal expression that is "tentative and exploratory" (Dickstein 2000: 137) and cannot bear any limitation. The juxtaposition of these assumptions leads to an "unavoidable conflict" (Dickstein 2000: 137), one that could be avoided, that is, only if any one of the two assumptions were modified. ${ }^{4}$

4 Dickstein vacillates between seeing the impossibility as stemming from the limiting or limitless (and so irreducible to poetry) nature of faith; therefore, his stance is a combination of T.S. Eliot's ('limiting' position) and Johnson's ('limitless' position) argument. In Polish criticism, a similar argument is made by Edward Kasperski, though here the discussion is about literature in general - Kasperski, making analogous presuppositions concerning religion and literature as Dickstein, pronounces the impossibility of religious literature to achieve the status of "artistic literature" (Kasperski 2006: 27). Here the affiliation is clearly with T.S. Eliot's version of the "impossibility of religious poetry" argument. 
An approach which might be seen as a borderline case between narrow and broad descriptions of religious poetry is that of Maria Jasińska-Wojtkowska. It is narrow in the sense of providing a concise definition of "religious poetry" as works in which "the speaker appears to be a homo religious" or in which "the speaker's experience of the relationship with the sacred constitutes the semantic dominant of the work" (Jasińska-Wojtkowska 2003: 37). It is also narrowing in the sense of explicitly limiting its understanding of poetry to lyrical poetry, and so focusing on its expressive function - a presupposition arguably shared by any expressively oriented definition, even if not stated openly in other studies discussed above. However, Jasińska-Wojtkowska provides at the same time a broad definition of religion that forms the background of her definition (religion as the "entirety of experiences and personal attitudes as well as socio-cultural events and structures that express in various ways the relationships between the human being and the transcendent" [Jasińska-Wojtkowska 2003: 36]), thus not limiting herself to one specific understanding of a religious act or experience. She explains how, based on her preliminary definition, one may study religious poetry on five different planes: 1 . The concept of the sacred emerging from a poem (from indefinite to specific to a given religion); 2 . The qualitative character of the relationship between the homo religious and the sacred (from affirmation to rebellion); 3. The anthropological character of the relationship (whether it is based on the intellect, will, or feeling, or a combination of those); 4. How the relationship is unfolded (directly or indirectly, through specific elements of the "sacrosphere", transcendental values, or thematic or stylistic references to religious texts); 5 . The place of the sacred in the structure of the work (central to marginal) (Jasińska-Wojtkowska 2003: 37-38). Jasińska-Wojtkowska offers here a methodological insight into studying religious poetry more than merely a prescriptive definition of the term. ${ }^{5}$

\section{Typological Approaches: Multi-Faceted Definitions of "Religious Poetry"}

Among scholars whose definitions seem to aim at illustrating the complexity of the term "religious poetry" more than the homogeneity of the phenomenon are David Jasper and, on the Polish side, though drawing on English criticism, Piotr Wilczek. In his discussion of the difficulties involved in attempts to define religious poetry, Piotr Wilczek assumes Gardner's definition (religious poetry

5 Jasińska-Wojtkowska's discussion of religious poetry is also to be found in Problematyka badań nad liryka religijna (rpt. in Tytko 2014: 25-26). It needs to be added that Jasińska-Wojtkowska's two studies on religion and literature at large, reprinted in the same book as the article discussed here, present a more exhaustive, broader theoretical basis for the literary study of religion and literature (not only poetry). 
as "poetry that treats of revelation and of man's response to revelation") as his "working definition", since he regards it to be "the most convincing and universal" of the ones he is familiar with (Wilczek 2001: 210). His aim is to illustrate the diversity of religious poetry, as defined by Gardner (Wilczek 2001: 210). He proposes four categories of poems that the definition embraces, which seem to be ordered so as to form a continuum, from the least to the most genuinely concerned with religious matters. The four categories are:

1. Works which use religious symbolism and religious themes to speak of the nonreligious;

2. Works which use religious symbolism to question religious truths;

3. Works which are an expression of religiousness, but which interpret religious truths in their own, idiosyncratic way;

4. Poetical works which fulfil a liturgical (ritual), devotional or catechetical function (which - contrary to appearances - is not tantamount to them being of an orthodox character) (Wilczek 2001: 214).

Wilczek's classification serves to present the complexity behind any attempt at defining religious poetry and to illustrate that "the richness of religious poetry is so vast that it escapes any divisions and does not conform to simplistic definitions" (Wilczek 2001: 222). In fact, Gardner's understanding of religious poetry is narrower than this categorization would suggest, and groups one and three are actually in conflict with her line of argumentation (one, because one can hardly speak of religious commitment in such cases; three, because for Gardner religious poetry is not a matter of expressing "personal discoveries").

David Jasper, in his Study of Literature and Religion, in a manner analogous to, and to a considerable extent overlapping with, Wilczek's, "consider[s] four states of the relationship between Christian belief and poetry" (Jasper 1992: 10). First, one may claim that such a relation is impossible or rarely established in practice (Jasper 1992: 12-13). The second stage is illustrated by poetry which treats Christian "images, rites and dogma" as a "great poetic resource" (Jasper 1992: 13). The third stage Jasper distinguishes is reserved for poets whose poetry expresses commitment to the Christian "vision and story" (Jasper 1992: 17-22). The fourth category comprises devotional verse, that is "poems with a specific task to do. They have to be sung, and to be immediately comprehensible to a congregation. They are an adjunct to worship and not solitary reflections upon religious experience. They are concerned with Christianity in its public form, as doctrine" (Jasper 1992: 23; emphasis original). The two sets of categories were formulated independently - Wilczek does not refer to Jasper's study in his work - yet there are clear correspondences between particular types described by the 
scholars. First, the scales that the critics construct are some versions of a scale of orthodoxy or of religious engagement. Secondly, Wilczek's second and third category and Jasper's second category would correspond to those definitions of religious poetry which focus on its expressive character; Wilczek's fourth group, as well as Jasper's fourth stage, would in turn coincide with definitions oriented toward the impressive and catechetical functions.

Edyta Sołtys-Lewandowska builds her theoretical framework around the notion of the speaker in the poem, her axis of categorization being drawn along the lines of religious involvement, similar to those of Wilczek's and Jasper's typologies. She first discusses various studies dealing with the subject of religion and literature and, based on that, proposes a typology of religious poetry and types of speakers in religious poems, never formulating an overarching definition of religious poetry, and leaving the final decisions as to whether a given poem is religious or not to particular scholars, depending on the criteria and methodology assumed in their studies and their sensibility (Sołtys-Lewandowska 2015: 177). The proposed types of religious poetry include: 1 . Theological poetry, which treats of basic theological concepts, either in abstraction or as related to human experience (Sołtys-Lewandowska 2015: 179-180); 2. Confessional poetry, in which the speaker is in personal contact with the Absolute and is looking for a personal relationship with it - this is religious poetry in the strict sense of the term, as Soltys-Lewandowska explains. She includes devotional poetry, kerygmatic poetry, mystical poetry and poetic credo under this category (Soltys-Lewandowska 2015: 180-185); 3. Questing poetry, in which the speaker tries to find traces of the transcendent in the contact with reality (Soltys-Lewandowska 2015: 186); 4. Poetry of the sacred - the broadest category comprising poetry in which the speaker searches for the transcendent, the mystery, the religious experience (Soltys-Lewandowska 2015: 186-187). The poetic voices represented in these various types of religious poetry include, according to Soltys-Lewandowska, homo quaerens, homo religious, homo novum (converted man, transgressing man), homo electus (Sołtys-Lewandowska 2015: 188-202).

\section{Broad Approaches: Studying the Religion-Poetry Relationship}

The alternative to formulating a single definition or several "sub-definitions" of religious poetry is the discussion of relationships between religion and poetry and of possible approaches to the study of the two interacting with each other. Kevin Hart, whose essay would belong to this category, does not discuss these relationships in great detail, focusing instead on the complexity of the two categories, which leads him to formulating a metaphor for how he understands the very 
mechanics of the interaction between the two in the form of religious poetry. $\mathrm{He}$ first provides a cross-section of possible understandings of what poetry is - the distinctions being made along formal lines (Hart 1994: 23-24) - and a variety of understandings of religion including concepts of religion characteristic of many different faiths, both those based on transcendence and immanence, and ranging from theological to sociological, mythological or mystical to philosophical, institutional to personal, inner experience to observance of rites to customs and habits associated with belief to moral conduct, commitment to doubt to rejection (Hart 1994: 24-28) - a truly inclusive summary of what religion may mean to different people in different parts of the world, contexts and times. After discussing this wide range of possible takes on what poetry and religion are, and observing that the scope of attitudes to religious poetry ranges from rejecting the possibility of religious poetry to acknowledging that all poetry is at its core religious, Hart concludes that a strategy more fruitful than trying to establish "a discrete body of work abiding ideally in the space marked out by three overlapping sets" (Hart 1994: 31) ${ }^{6}$ would be to resort to the concept of family resemblance. Using Wittgenstein's metaphor of spinning a thread whose strength "does not reside in the fact that some one fibre runs through its whole length, but in the overlapping of many fibres" (Hart 1994: 31), Hart assumes that both "poetry" and "religion" "are threads made from the overlapping of various fibres, not any one of which runs through the whole length". In other words, there may be poems termed religious that would seem to have nothing in common, but that are connected through family resemblance -having something in common with another religious poem.

If Hart focuses on the very form of conceptualizing the religion-poetry relationship, Zofia Zarębianka moves in her study from the broadest possible to a narrow perspective in discussing various shapes and varieties that this relationship was seen to take. She distinguishes two levels at which to consider this subject: the first level, pertaining in general to the correspondences between religion and literature, ${ }^{7}$ and the second, where one identifies only certain

${ }^{6}$ The third set here is "Australian". The remarks in Hart's article are based on the recollection of his experience of composing an anthology of Australian religious poetry.

Relationships between religion and literature described here are elaborated on in chapter two of Zofia Zarębianka's Czytanie Sacrum (2008). One of the leading scholars in the field in Poland, Zarębianka discusses various issues connected with the theory and methodology of studying religious poetry/the sacred in poetry also in O poezji religijnej i sposobach jej badania (1990), Poezja wymiaru sanctum: Kamieńska, Jankowski, Twardowski (1992) and in her introduction to Tropy sacrum w literaturze XX wieku: Od zagadnień motywicznych do perspektyw hermeneutycznych (2001: 9-18). 
poetic works as religious. ${ }^{8}$ In the context of the former, the scholar discusses various theoretical statements that treat all poetry or all art in general as at its core religious (Zarębianka 1991: 71-72); cites scholars who pointed to the role of religion in the development of the Western literary tradition (Zarębianka 1991: 72-73); examines the relationship between religion and poetry in terms of their common aim - unveiling what is hidden - and thus of the analogous subject matter and language of poetic and religious expression (Zarębianka 1991: 73-74); comments on the similarities and dissimilarities between the poetic and the mystical, on poetry and religion as expressions of a certain worldview (Zarębianka 1991: 75), and on the possible analogies in functions of religious and literary expression (Zarębianka 1991: 78). The second level is that of studying religious elements in a literary work, the speaker's attitudes towards the sacred and ways of communicating them, religious genres and language as well as the criteria of classifying certain works as religious. Among the extra-textual criteria sometimes used, enumerated but rejected by Zarębianka are the beliefs of the actual author (not the implied author), readers' reception (again, actual, not implied) and a poem's religious or non-religious use (Zarębianka 1991: 78-79). Zarębianka recognizes only the textual criteria as valid in defining what belongs to religious poetry and quotes Jasińska-Wojtkowska's five categories that can be considered in studying religious poetry (see above). In her later work, Zarębianka resigns from using the term "religious poetry" whatsoever, deeming it too pejoratively charged (it being equalled with "minor poetry", in the sense in which T.S. Eliot described it as such) (Zarębianka 2008: 28).

8 An analogous distinction, pertaining to literature at large, is to be found in Dybciak, but Zarębianka's study is in this respect also applicable to works other than poetry. Dybciak, just like Zarębianka, though in a more pronounced way, creates an analogy between these two levels and two concepts of the sacred: following a universal conception (the whole world belonging to the sacred, its every element being in a relationship with God), studying religious aspects of poetry (literature, art) will consist in sacralizing it, assuming that all poetry is religious, either because of some external factors, such as its subject, origins, purpose, or immanent elements such as its form, structure, meaning, symbolism; assuming a selective conception (the sacred constituting only a part of the reality, the rest of it belonging to the profane) results in a selective approach also in studying poetry, that is, differentiating between religious and non-religious works of literature and pointing to religious elements within works of literature (Dybciak 2005: 24-27). Dybciak further develops his conception by distinguishing within the selective approach two types of relationships between literature and religion which lend themselves to study: social (those pertaining to the origin and function of a given text, in other words to the place of the text in its social context) as well as structural (those that, unlike the former type, which requires sociological methods, can be analyzed within the discipline of literary studies, since they involve literary analysis of the form and content of a work) (Dybciak 2005: 28-31). Dybciak's categorization might be seen as a more structured, systematized version of Zarębianka’s general concept. See also: Sawicki 1979; Gutowski 1994, and Jasińska-Wojtkowska 2003 (chapters 2 and 4) for similarly broad takes on the directions which studies of religion and literature (including, but not limited to poetry) may assume. 
Edward Balcerzan's take on the poetry-religion intersections corresponds to Sołtys-Lewandowska, Wilczek and Jasper in the sense that all these scholars seem to build frameworks of different types of the poet's (Jasper) or the speaker's (others) engagement with religious material. The difference is that Balcerzan's division is structural and not content-based and so it offers a method of studying religious elements in poetry rather than a typology of religious poems. What is important here is not so much what the speaker says about religious elements but in what kind of relationship to other elements of the poem's reality it places them. Balcerzan distinguishes two levels on which the "religious horizon" can manifest itself in poetry: the primary, descriptive (or paradigmatic) level, which is the occurrence in a poem of religiously marked lexis (objects of religious cult, fragments of prayers or holy scriptures, elements of rituals etc.); and the secondary, interpretative (or syntagmatic) level, which involves approaching a poem's religious horizon through the prism of religious, anti-religious or a-religious secondary modelling systems (Balcerzan 2015: 282-283). According to Balcerzan, each of these three systems will involve a different approach to the primary, descriptive level in terms of metaphorics: religious modelling will involve a literal, non-metaphorical reading of these elements, treating them as just as real as, for example, the speaker in the poem; "the basic figure of the antireligious system and its poetics is the substitutional metaphor that questions the literalness of the religious narrative" (Balcerzan 2015: 293); the poetics of a-religious modelling will not be engaged in the belief-disbelief conflict, giving instead an account of the presence of religion in culture and language. The use of religious vocabulary in this way, often in the form of comparative metaphors, requires neither acknowledging nor rejecting the realness of the religious narrative behind the references evoking it within the represented world of the poem (Balcerzan 2015: 286). A given work need not be based on only one of the three systems, and it can be a combination of, for example, an a-religious opening with a religious conclusion, or any other configuration (Balcerzan 2015: 287). It may also be the case that the primary, descriptive level does not provide enough information to interpret it through the prism of any single model. Finally, a given interpreter may impose their own modal frame on a poem, so that the global sense of one and the same text can be religious, antireligious or a-religious, depending on the values a given interpreter brings to their reading (Balcerzan 2015: 288).

Through the use of the category of the metaphor and the relationship it builds between the speaker in the poem and the descriptive level of religious lexicon, Balcerzan's study enables the categorization and analysis of the use of religious elements in poetry which is firmly grounded in textual, and not extra-textual premises such as the author's religious affiliation or their need for/ 
doubt/opposition against the transcendent, the history of a poem's devotional use, "sincerity" or "orthodoxy" of religious expression. But Edward Balcerzan's concept is interesting also because of its potential to function not only as literary criticism of religious poetry but also as meta-criticism of theoretical approaches to it. To borrow Balcerzan's categories, some studies mentioned in this survey focus on poetry that uses religious modelling (Pezzini, Tsur), some may be prone to impose religious modelling where the text does not justify it (a common objection against kerygmatic approach), but some of them seem to use religious modelling themselves in framing their own critical discourse - in other words, in order to understand their argument one needs to assume the realness of the religious concepts they refer to on the descriptive level. In this sense they belong to theology more than literary studies. The religious modelling of critical discourse is evident in, for example, Jasper's work, which explicitly affiliates itself with theology - he states in the preface to his book that its aim is to point out "the importance of the reading of literature for theology, and, conversely, of the inescapably religious end towards which the study of great works of the imagination points us" (Jasper 1992: xi). His categorization ultimately serves to "[release] religious and Christian verse from the limitations of a specific category within literature", which is to lead to "ask[ing] of theologians how they might see poetry and poetic inspiration contributing to their task" (Jasper 1992: 31). Another example of the religious modelling of critical discourse is Gardner's work, which is more surprising given that she, unlike Jasper, is a literary scholar and not a theologian or a representative of religious studies. Nonetheless, at its core, her definition seems to be in closer proximity to theology than literary studies, inasmuch as it is aimed at helping understand religious poetry as a religious rather than a literary phenomenon. For Gardner, "the interest and value of studying 'religious poetry' as a genre lies [...] in the variations from age to age in the concept of religion and the concept of poetry and the interactions between them" (Gardner 1983: 122), but the final goal of such inquiries seems to be an insight into the revelation itself:

since revelation is of necessity made in place and time, and since all that is received can only be received according to the capacity of the receiver, the substance of what is claimed to be, or is presented as, eternal truth is intricately entwined with the accidents of time and place and human personality. We may come nearer recognizing the substance if we accept our limitations as historical beings and concentrate on the accidents (Gardner 1983: 135).

Religious poetry expresses a person's response to revelation, Gardner claims, but the sum of these expressions is synergic, as, according to her, it enables us to 
abstract from these particular expressions, in an Aristotelian manner, the essence of eternal truth. In contrast to that, Balcerzan's study, as well as those by Hart or Jasińska-Wojtkowska, to name just a few examples, would be representatives of the a-religious modelling of critical discourse, to borrow Balcerzan's term, since their theoretical frameworks do not necessitate the acceptance (nor the rejection) of the existence of the religious truths to be revealed, or the realness of any other objects of religious belief.

\section{Conclusion: Some General Tendencies and (Potential) Deficits}

The overview proposed above does not include theoretical approaches to religious literature at large, limiting itself specifically to poetry, but a preliminary research suggests that the observations on scholarship focusing on theoretical aspects of religious poetry translate into the general tendencies in the studies of religious literature. The list of theoretical studies of religion and literature in Polish is even more extensive than that of studies on religion and poetry. ${ }^{9}$ The broad studies of the relationship between religion and literature in English are slightly more numerous than those focusing specifically on poetry, ${ }^{10}$ yet critics point to the deficit in this kind of studies nonetheless. In 1998, Taylor recognized a "current scholarly void", stating that "[a] great critical need of our time is for ways of discussing religious or spiritual dimensions in works of literature" (Taylor 1998: 3). Two decades later, and the authors of one of the chapters in the Routledge Companion to Literature and Religion still express their surprise at discovering how lacking the genuine debate on defining the field of study is in the pages of journals devoted to the studies of religion/theology and literature, where one would expect such a dialogue to be taking place (Bauer, Zirker 2016: 60). Indeed, the most easily discernible difference between Polish and Anglophone

9 See: Dybciak 2005; Gutowski 1994; Jasińska-Wojtkowska 2003; Kudyba 2013; Martwicki 1995; Nowaczyński 1996; Sawicki 1979, 1980, 1994, 2007; Tomaszewska 2014; Zarębianka 2008; Zambrzycka 2010.

${ }^{10}$ See Gunn 1979; Taylor 1998; The Oxford Handbook of English Literature and Theology (2007); Knight 2009; The Routledge Companion to Literature and Religion (2016), and a special issue of the journal Religion and Literature from 2009 devoted to the question "What is religion and literature?". The journal is oriented towards theology rather than literature, inviting submissions on literature "in conjunction with important religious or theological issues that emerge from the literary text or that illuminate it. The journal is also open to receive essays in which theology is elucidated, extended or challenged by literature. No religious or theological perspective is excluded" (Journal of Religion and Literature website 2019). This submissions profile summarizes the angle of the substantial part of the debate in the special issue in question. But see articles by Kort, E. Ziolkowski, Hart and Middleton for some insights into defining the scope of studies of religion and literature, and into the development and the current state of and problems involved in this area of research in British and American scholarship. 
theoretical approaches to religion and poetry/literature is that Polish studies are in a dialogue with each other, building on previous works by either polemicizing with or developing on the earlier studies, while the latter do not show this kind of continuity. ${ }^{11}$ The little debate there is in Anglophone scholarship is dominated by experts in religious studies, and thus it is very different in character from the one preoccupying Polish literary scholars. Among Polish scholars, the debate revolves around the place of the literary approach within the larger context of the study of religious literature in different disciplines, the proper literary methods of studying religious literature and the very utility of the terms "religious poetry/literature", an alternative (or complementary) approach being the use of the notion of poetry and the sacred (sacrum), where "sacrum" is attempted at being defined and applied as a historical-literary category rather than one belonging to religion or theology. ${ }^{12}$ The focus is also on distinguishing between methods and terminology suitable for and going beyond literary studies (hence the distinction between literary studies of religion and literature and the theology of literature, the kerygmatic approach, ecumenical criticism, and the sociological and cultural studies of the reception and use of religious literature) ${ }^{13}$ In Anglophone scholarship, the emphasis is put on the distinction between theological/apologetic/confessional approaches (Polish "theology of literature" and the "kerygmatic approach") and those oriented towards religious studies, there being no particular interest in working out common methodologies and hardly any literature-oriented voices in this debate. ${ }^{14}$

Apart from this general observation, the survey of Polish and Anglophone approaches to religious poetry suggests the following:

${ }^{11}$ The said continuity in Polish literary studies of religion and poetry may stem from the fact that the majority of the leading scholars in the field are affiliated with the same research centre (Catholic University of Lublin). The lack of such a continuity in Anglophone studies was observed by Wesley A. Kort, who stated that though the study of religion and literature "has been going on for more than half a century, rarely does work done now refer to or build on what has gone before" (Kort 2009: 106). One may see as symptomatic of this lack the fact that there is no extensive overview of previous work in general monographs such as The Oxford Handbook of English Literature and Theology and An Introduction to Religion and Literature or a seemingly random selection of case studies summarized by Simon Brittan under Religion and Literature in Reader's Guide to Literature in English (1996).

12 See Kudyba 2013; Zarębianka 2008: 11-17; Sawicki 1980, 1994, 2007; Nowaczyński 1996.

13 See: Gutowski 1994: 5-23; Dybciak 2005: 28-35.

${ }_{14}$ The lack of understanding of the literary-critical perspective was recognized by Theodore Ziolkowski, the author of the only literature-oriented, "polemical" (or one could say self-defensive) contribution to the special issue of "Religion and Literature" mentioned above. See also footnote 19 below. 
1. Many of the definitions or descriptions of religious poetry in both Polish and Anglophone traditions (Gardner, Jasińska-Wojtkowska, Pezzini, Wilczek, Zarębianka, Balcerzan) try to accommodate themselves to the whole range of attitudes to the sacred, not only the affirmative, but also the doubtful and rejecting ones - in other words, they try to embrace the poems in which one sees resonating the diagnosis that God is dead. At the same time, studies of religious poetry are less prone to acknowledging another death that was pronounced in the twentieth century, namely that of the author, and this is regardless of whether they were formulated before or after the publication of the 1967 essay by Roland Barthes. ${ }^{15}$ This tendency was recognized by Jasińska-Wojtkowska, who pointed out that biographism and psychologism, approaches which a literary scholar is generally inclined to renounce in principle, easily regain their otherwise lost entitlements in the studies of religious poetry (Jasińska-Wojtkowska 2003: 31). Jasińska-Wojtkowska leaves the readers of her article with an open question as to whether this return is always a matter of a conscious scholarly choice.

2. While trying to, in the words of one anthologist, "broaden the meaning of the term 'religious' to accommodate twentieth-century sensibility" (Thomas 1963: 9), the studies seem to narrow it down at some other end, therefore losing sight of some forms of religious poetry. What I mean here is the insufficient recognition, in both Anglophone and Polish scholarship, of the social, community-forming function of religion and therefore no recognition of the potential of religious poetry to perform the phatic function in this dimension - i.e. its potential as a carrier of religious content which serves to develop a bond not only with the sacred, but also between the members of a given interpretive community. Although verging on sociological studies, the recognition of this function is important for a literary critic inasmuch as it opens the inquiry to types of poetry otherwise not fitting into the frameworks designed by scholars operating within the definitions of what Boglioni refers to as "official religion" and its three facets: juridico-pastoral, theologico-scientific, and mystico-spiritual (Boglioni 1977: 702). The recognition that religious poetry may participate in religion understood in a different way than this tripartite division suggests - in other words that it may be part of popular piety - is particularly useful in studying popular and medieval religious poetry.

${ }^{15}$ See for example essays in the collection The Oxford Handbook of English Literature and Theology, where, as Wesley A. Kort observes in his review, "[1]iterary texts are treated primarily as occasions to infer the beliefs of their authors. This method accounts for the emphasis placed in the collection on poetry since poetry often is taken, among the genres, as providing continuity between texts and authors" (Kort 2009: 109). Of the studies discussed in this overview, the focus on the author is visible in Gardner and Jasper. 
3. While none of the studies discussed above explicitly states its affiliation with a particular religious orientation, they tend to share the view of religion as an extraversive, as opposed to an introversive system, that is, they conceive of religion as the relationship of homo religiosus with the sacred that is outside of man, not within her/him (Bowker 1997: xvii). In practice, the studies dealt with here are mostly designed so as to be applied to religious poetry that does not stand in fundamental contradiction to Christianity, Judaism and Islam - the three main extraversive religious systems - or, in some cases, treat "Christian" and "religious" as synonyms and are construed with this specific religion in mind. This could be recognized as a potential deficit in theoretical studies. On the other hand, to assume the frameworks of an extraversive religious orientation or specific religious faith is an understandable filter in studies focused on poetry produced within the Western cultural traditions. ${ }^{16}$ While narrowing the scope of theoretical interest in order not to create a term that is too broad to be meaningful is understandable, an even greater sensitivity to the non-synonymous use of the terms "religious" and "Christian" in criticism could clear up the terminological confusion in some of the Polish and Anglophone studies. This may as well be already a problem of the past, since more recent scholarship seems to be more cautious in this respect.

4. Similarly, narrow prescriptive definitions and religious modelling can be seen as either a justified choice or a deficit, depending on the context (e.g. on the disciplinary affiliation and purpose of a given study). ${ }^{17}$ I would argue that they are signs of a deficit from the point of view of literary studies, and one which especially Anglophone scholarship of religious poetry suffers from. The main problem is not that there are absolutely no English studies moving beyond a prescriptive typology and religious modelling of critical discourse characteristic of a theological orientation, or that it is prevalent in English while being marginal in Polish scholarship. Quite to the contrary, Polish scholarship abounds in studies that represent the extreme end of the spectrum in these respects. ${ }^{18}$ The difference is that in Polish scholarship it is a matter of a conscious choice, the whole spectrum being often sketched in particular studies before they explain their own theoretical and methodological stands, however narrow and close to the extreme

${ }^{16}$ Although even in such case this kind of congruity is not necessary, as Meyer and Deshen's "outside reading" (or "reading through resistance") of Christian poetry with the use of Jewish hermeneutics (as opposed to "reading through identification," i.e. adopting Christian hermeneutic, meditative, contemplative, mystical, liturgical frame of reference) once illustrated (see Meyer, Deshen 2010: 4-5).

${ }^{17}$ David Jasper, with his theological orientation, identifies "fail[ing] to attribute a specific or serious task to theology" (Jasper 1992: 28) to be the source of confusion that he sees in literary critics' writings on religious poetry.

${ }^{18}$ An example of it being the "kerygmatic" trend in the analysis in works of literature. 
end of the spectrum these may be; and if this is not the case, then there are separate studies providing such broad frameworks against which particular approaches are oriented. Perhaps the lack of a specific disciplinary and methodological affiliation in the criticism of religious poetry in English stems from the fact that the studies implicitly affiliate themselves with a multidisciplinary field referred to, especially in American criticism and predominantly by religious studies scholars, as "religion and literature". This term is, however, problematic - Kort states that "religion and literature" is not a field of studies because it lacks

delimited terrain, pioneers and predecessors whose work forms a foundation upon which advances could be made, some established methods, standards specific to it by which the quality of work and its contribution to the field could be judged, and shared goals $[\ldots]$ though it has been going on for more than half a century, rarely does work done now refer to or build on what has gone before; it is methodologically uncertain; it lacks standards that would indicate when work makes an advance upon which others can build (Kort 2009: 105-106).

He concludes that the term "interest" would better render the "often quite personal and variable nature" of works on religion and literature (Kort 2009: 106). ${ }^{19}$ In the light of the above, a viable alternative to operating within the vague general frameworks of "religion and literature" could be, as is the case in Polish criticism, to delineate the disciplines (literary studies, religious studies, cultural studies, sociology, theology) within the scopes of which such interests can be pursued, and to establish methods useful in the field of religion and poetry/ literature as studied within these particular disciplines.

The final question is whether such tight theoretical frameworks and clear-cut divisions into subfields belonging to different disciplines are indeed necessary ${ }^{20}$ and whether their usage or absence has any bearing on studies analyzing poetry

${ }^{19}$ See also Eric Ziolkowski (2009), who remarks that the "chief problem with religion and literature, one that affects both the self-understanding of its proponents and the ways it is perceived by scholars in other areas in the academy, is that those working 'in R\&L' have never fully clarified the implications of the evolvement of their field from theology and literature. Examining literature theologically, and examining literature in accordance with the multicultural, anti-apologetic strictures of religious studies, are two distinct activities. I am emphatically not suggesting that either of these approaches is better or somehow more valid than the other, but only that they are different and should not be confused or conflated with one another, as they often are" (E. Ziolkowski 2009: 130). He points to the confusion between religious and theological studies of religion and literature, because that is where most of the discussion of the subject is located, but the matter gets more complicated once other disciplines, including literary studies, are added on top of that.

${ }^{20}$ See Gunn (1979: 10) for an argument that it is unnecessary, or even disadvantageous for "authentic humanistic research" to have this field strictly defined and divided along disciplinary lines. 
and the efficiency of their methodologies. The question is valid, especially given that such studies will, after all, always remain multidisciplinary and interdisciplinary in some sense and, secondly, that the deficit in Anglophone literary theoretical studies on the subject and its limited attempts at systematizing the field do not translate into a scarcity of analytical studies of religious poetry, literary ones included. I would argue that producing prospective translations into English and thus providing international access to Polish criticism would be beneficial - if not in the sense of influencing the quality or quantity of Anglophone analyses and interpretations of religious poetry, then as a means to simply facilitate the research in the field, that is, to give perspective on the bulk of studies on the subject originating from different disciplines, and to help affiliate Anglophone critics' work to their primary discipline. Access to studies that clearly structure the domain of religion and poetry/literature studies could make it easier for prospective researchers to clearly situate their projects, methods and goals within those frameworks and to select secondary sources with a goal analogous to their own, whether this goal is to learn what studying religious poetry may bring to our understanding of literature, of believers, or of the sacred itself.

\section{BIBLIOGRAPHY}

Balcerzan Edward. 2015. Religijne i metafizyczne horyzonty polskiej liryki. "Teksty Drugie", no. 3. ISSN: 0867-0633. Pp. 280-294.

Bauer Matthias, Zirker Angelika. 2016. Modern Debates: Christianity and Literature, Literature and Theology, and Religion and Literature. In: The Routledge Companion to Literature and Religion. Ed. Mark Knight. Abingdon: Routledge. ISBN: 978-02-0349891-0. Pp. 58-68.

Boglioni Pierre. 1977. Some Methodological Reflections on the Study of Medieval Popular Religion. "Journal of Popular Culture", no. 11. ISSN: 1540-5931. Pp. 697-705.

Bowker John. 1997. Introduction. In: The Oxford Dictionary of World Religions. Ed. John Bowker. ISBN: 978-01-9866-242-6. Pp. xv-xxiv.

Brittan Simon. 1996. Religion and Literature. In: Reader's Guide to Literature in English. Ed. Mark Hawkins-Dady. eBook edition. London: Fitzroy Dearborn. ISBN: 978-020330-329-0. Pp. 1190-1192.

Chrzanowski Ignacy. 1935. Na szczytach polskiej liryki religijnej. "Pamiętnik Literacki", vol. 32, no. 1/4. Pp. 68-83.

Dickstein Morris. 2000. Is Religious Poetry Possible? "Literary Imagination: The Review of the Association of Literary Scholars and Critics", no. 2. ISSN: 1523-9012. Pp. 135-151. 
Dybciak Krzysztof. 2005. Trudne spotkanie: literatura polska XX wieku wobec religii. Kraków: Arcana. ISBN: 8-3892-4308-3.

Eliot T.S. 1963. Religion and Literature. In: Modern Criticism: Theory and Practice. Ed. Walter E. Sutton, Richard Foster. Indianapolis: Odyssey. ISBN: 978-08-9197853-4. Pp. 150-157.

Gardner Helen. 1983. Religion and Literature. Oxford: Oxford University Press. ISBN: 0-1981-2824-X.

Gunn Giles. 1979. The Interpretation of Otherness: Literature, Religion, and the American Imagination. New York: Oxford University Press. ISBN: 0-1950-2453-2.

Gutowski Wojciech. 1994. Wśród szyfrów transcendencji: szkice o sacrum chrześcijańskim w literaturze polskiej w XX wieku. Toruń: Wydawnictwo UMK. ISBN: 8-3231-0534-7.

Hart Kevin. 1994. Australian Religious Poetry. In: Religion, Literature and the Arts Project: Conference Proceedings of the Australian International Conference 1994. Ed. Michael Griffith, Ross Keating. Sydney: Australian Catholic University. ISSN: 1444-5158. Pp. 23-36.

Hart Kevin. 2009. Religion and Literature? "Religion and Literature", no. 2. ISSN: 0888-3769. Pp. 143-147.

Jasińska-Wojtkowska Maria. 2003. Horyzonty literackiego sacrum. Lublin: Wydawnictwo KUL. ISBN: 8-3736-3042-2.

Jasińska-Wojtkowska Maria. 2014. Problematyka badań nad liryka religijna. Rpt. in: Marek Mariusz Tytko. O "Poezji Religijnej i Sakralnej". Religious and Sacred Poetry: An International Quarterly of Religion, Culture and Education”, no. 2. ISSN: 22999922. Pp. 19-42.

Jasper David. 1992. The Study of Literature and Religion: An Introduction. $2^{\text {nd }}$ ed. Basingstoke: Macmillan. ISBN: 978-13-4922-124-0.

Johnson Samuel. 1905. Lives of the English Poets. Vols. 1-3. Oxford: Clarendon.

Kasperski Edward. 2006. Literatura a religia: różnice, korelacje, funkcje. In: Język religii: konstrukcje i dekonstrukcje. Ed. Lucyna Rożek. Częstochowa: Akademia Jana Długosza. ISBN: 8-3709-8990-X. Pp. 15-32.

Knight Mark. 2009. An Introduction to Religion and Literature. London: Continuum. ISBN: 978-08-2649-702-4.

Kort Wesley A. 2009. What, After All, Is Religion and Literature? "Religion and Literature", vol. 41, no. 2. ISSN: 0888-3769. Pp. 105-111.

Kudyba Wojciech. 2013. Sacrum i "duchowość" w polskich badaniach literackich. "Religious and Sacred Poetry: An International Quarterly of Religion, Culture and Education”, no. 1. ISSN: 2299-9922. Pp. 59-77.

Martwicki Krzysztof. 1995. Raport w sprawie teologii literackiej. "Studia Płockie", no. 23. ISSN: 0137-4362. Pp. 89-99. 
Meyer Kinerth, Deshen Rachel Salmon. 2010. Reading the Underthought: Jewish Hermeneutics and the Christian Poetry of Hopkins and Eliot. Washington, D.C.: Catholic University of America Press. ISBN: 978-08-1321-742-0.

Middleton Darren J.N. 2009. Literature and Religion's Unfinished Story. "Literature and Religion”, no. 2. ISSN: 0888-3769. Pp. 149-157.

Nowaczyński Piotr. 1996. O badaniach nad literatura religijna w KUL. In: Religia a literatura w publikacjach KUL: 1918-1993. Ed. Jan Gotfryd et al. Lublin: Redakcja Wydawnictw KUL. ISBN: 83-2280-538-1. Pp. 7-21.

The Oxford Handbook of English Literature and Theology. 2007. Ed. Andrew Hass, David Jasper, Elisabeth Jay. Oxford: Oxford University Press. ISBN: 978-01-9927-197-9.

Pezzini Domenico. 2003. Religion and Poetry: "An Ill-Assorted Pair of Horses Bridled Together"? In: Rites of Passage: Rational/Irrational Natural/Supernatural Local/Global. Ed. Carmela Nocera, Gemma Persico, Rosario Portale. Soveria Mannelli: Rubbettino. ISBN: 978-88-498-0657-1. Pp. 45-65.

Piekarski Ireneusz. 2014. Interpretacja kerygmatyczna a tradycje i perspektywy badań literackich. In: Interpretacja kerygmatyczna: doświadczenia, re-wizje, perspektywy. Ed. Jarosław Borowski, Edward Fiała, Ireneusz Piekarski. Lublin: Wydawnictwo KUL. ISBN: 978-837702-888-9. Pp. 21-45.

The Routledge Companion to Literature and Religion. 2016. Ed. Mark Knight. Abingdon: Routledge. ISBN: 978-02-0349-891-0.

Sawicki Stefan. 1979. Z pogranicza literatury i religii: szkice. Lublin: Redakcja Wydawnictw KUL.

Sawicki Stefan. 1980. Sacrum w literaturze. "Pamiętnik Literacki”, no. 3. ISSN: 00310514. Pp. 169-182.

Sawicki Stefan. 1994. Wartość - sacrum - Norwid: studia i szkice aksjologicznoliterackie. Lublin: Redakcja Wydawnictw KUL. ISBN: 8-3228-0432-6.

Sawicki Stefan. 2007. Wartość - sacrum - Norwid 2: studia i szkice aksjologicznoliterackie. Lublin: Wydawnictwo KUL. ISBN: 978-83-7363-635-4.

Sołtys-Lewandowska Edyta. 2015. O “ocalajacej nieporzadek rzeczy” polskiej poezji metafizycznej i religijnej drugiej potowy XX i początków XXI wieku. Kraków: Universitas. ISBN: 978-83-2422-716-7.

Taylor Dennis. 1998. The Need for a Religious Literary Criticism. In: Seeing into the Life of Things: Essays on Literature and Religious Experience. Ed. John Mahoney. New York: Fordham University Press. ISBN: 0-8232-1733-7. Pp. 3-30.

Thomas R.S. 1963. Introduction. In: The Penguin Book of Religious Verse. Harmondsworth: Penguin. Pp. 7-11.

Tomaszewska Wiesława. 2014. Homo religiosus a religijność literatury. "Świat i Słowo", no. 2. ISSN: 1731-3317. Pp. 131-146. 
Tsur Reuven. 2003. On the Shore of Nothingness: Space, Rhythm, and Semantic Structure in Religious Poetry and its Mystic-secular Counterpart. Exeter: Imprint Academic. ISBN: 0-9078-4544-4.

Wilczek Piotr. 2001. "Religijne” czy “niewyrażalne”? Wokót dawnych i wspótczesnych prób definiowania poezji religijnej. In: Dyskurs, przektad, interpretacja: literatura staropolska i jej trwanie we wspótczesnej kulturze. Katowice: Gnome. ISBN: 8-3878-1941-7. Pp. 210-223.

Zambrzycka Marta. 2010. Sacrum jako kategoria literacka. "Studia Humanistyczne”, no. 10. ISSN: 1641-8573. Pp. 105-112.

Zarębianka Zofia. 1990. O poezji religijnej i sposobach jej badania. "Roczniki Humanistyczne", no. 1. ISSN: 0035-7707. Pp. 25-56.

Zarębianka Zofia. 1991. Co to jest poezja religijna? "Horyzonty Wiary", no. 8. ISSN: 0867-0358. Pp. 71-82.

Zarębianka Zofia. 1992. Poezja wymiaru sanctum: Kamieńska, Jankowski, Twardowski. Lublin: Wydawnictwo Towarzystwa Naukowego KUL. ISBN: 8-3852-9125-3.

Zarębianka Zofia. 2001. Tropy sacrum w literaturze XX wieku: Od zagadnień motywicznych do perspektyw hermeneutycznych. Bydgoszcz: Homini. ISBN: 8-3879-3356-2.

Zarębianka Zofia. 2008. Czytanie Sacrum. Kraków-Rzym: Stowarzyszenie Pisarzy Polskich, Instytut Wydawniczy “Maximum”. ISBN: 978-83-9182-878-6.

Ziolkowski Eric. 2009. The Place not the Plans: Some Thoughts on Religion and Literature. "Religion and Literature", no. 2. ISSN: 0888-3769. Pp. 125-133.

Ziolkowski Theodore. 2009. Forum on Religion and Literature: A Mildly Polemical Position Statement. "Religion and Literature", no. 2. ISSN: 0888-3769. Pp. 197-203.

Joanna Matyjaszczyk

\section{APPROACHES TO RELIGIOUS POETRY IN POLISH AND ANGLOPHONE SCHOLARSHIP. A COMPARATIVE OVERVIEW}

(abstract)

The article compares Polish and Anglophone literary-theoretical approaches to religious poetry. It demonstrates that some common tendencies to be found in Polish studies and in English scholarship include drawing on a single religious tradition (Christian, official), focusing on the author and their religious experience, and narrow and/or prescriptive approaches that are sometimes more theological than literary-theoretical in nature. The survey suggests that the most prominent difference is that Polish criticism has produced a long-standing tradition of literary-theoretical studies that develop on or polemicize 
with each other in an attempt to describe and systematize the field of the intersections of poetry and religion and propose literary methodologies for studying religious poetry, while Anglophone studies do not enter into this kind of dialogue. The Polish studies, if popularized, could help reduce the theoretical and methodological deficit in Anglophone scholarship on the subject.

\section{SŁOWA KLUCZOWE}

literatura religijna; poezja religijna; teoria literatury; sacrum w literaturze 